\title{
Iodine content in goat and sheep milk related to herd size, seasonality, farming practice and breed effect
}

\author{
Marcela Klimešová ${ }^{1}$, Lenka Vorlová ${ }^{2}$, Hana Zachovalová ${ }^{2}$, Aleš Dufek ${ }^{1}$, \\ Ludmila Kř́žzová ${ }^{3}$, Lucia Hodulová ${ }^{2}$, Oto Hanuš ${ }^{1}$, Miroslav Skřivánek ${ }^{1}$, Hana Nejeschlebová ${ }^{1}$ \\ ${ }^{1}$ Dairy Research Institute, Prague, Czech Republic \\ ${ }^{2}$ University of Veterinary Sciences Brno, Faculty of Veterinary Hygiene and Ecology, \\ Department of Hygiene and Technology of Food of Animal Origin and Gastronomy, Brno, Czech Republic \\ ${ }^{3}$ University of Veterinary Sciences Brno, Faculty of Veterinary Hygiene and Ecology, \\ Department of Animal Breeding, Animal Nutrition and Biochemistry, Brno, Czech Republic
}

Received March 24, 2021

Accepted November 9, 2021

\begin{abstract}
Iodine is a milk micronutrient whose concentration is highly variable and depends on several factors. The aim of this work was to monitor the prevailing concentration of iodine in raw goat $(n=71)$ and sheep $(n=68)$ milk from farms in the Czech Republic, to assess the variation in iodine levels and evaluate them with farming practices, herd size, breed and season. Iodine was determined by a spectrophotometric method according to Sandell-Kolthoff. The mean prevailing iodine concentration in goat and sheep milk was 249.73 and $264.21 \mu \mathrm{g} / \mathrm{L}$, respectively. In addition to inter-species variability, we found statistically significant differences depending on the both sheep and goat herd size. The differences between conventional and organic farming were relatively minor and without statistical significance.
\end{abstract}

Organic milk, conventional milk, small ruminants, goat milk, sheep milk

Iodine intake continues to be a much debated subject. Iodine deficiency has been recognized as a major problem worldwide since the last century, and has reached pandemic proportions in practically all parts of the planet (Andersson et al. 2007; Kavř́ík et al. 2013; Řehůřková and Ruprich 2013). Current available data show up to 2 billion people living with insufficient iodine supply and almost the entire pregnant female population in Europe suffers from a lack of iodine due to insufficient iodine supplementation in the diet during pregnancy (Lazarus 2014). There were 31 countries worldwide with iodine deficiency in 1993, according to the World Health Organization (WHO) statistics. A suboptimal iodine status of pregnant women was found in nine countries (Albania, Belgium, Czech Republic, Greece, Israel, Norway, Portugal, Romania and Serbia) and the evidence of iodine deficiency in general, as well as the pregnant population, in five countries (France, Hungary, Ireland, Italy and the UK; WHO 1993). According to the data from the Iodine Global Network, based on median urinary iodine concentrations, iodine deficiency in 2017 was seen among school-age children and adults mostly in Italy, Finland and Ukraine, whereas Israelis showed one of the worst iodine deficiencies among schoolage children and pregnant women in the world (Iodine Global Network 2017). This means that inadequate iodine supply in pregnancy occurs in approximately $30 \%$ of European countries. Brazil, on the other hand, even had an excessive amount of iodine (Anders son et al. 2007).

Iodine deficiency has a negative impact on both humans and animals. The most serious disorders caused by iodine deficiency include brain damage and irreversible mental retardation, and it also has a negative effect on fertility (Sargison et al. 1998; Verma et al. 2012). Recent studies also describe an association between a suboptimal maternal 
iodine status during early pregnancy and worse cognitive outcomes in children (Costeira et al. 2011; Bath et al. 2013). Iodine deficiency during pregnancy leads to a disruption of thyroid hormone synthesis in the mother and a reduced supply of thyroid hormones to the foetus. An insufficient supply of thyroid hormones to the developing brain cells may result in congenital neurocognitive impairment (Zimmermann 2009).

Iodine is obtained through nutrition, being an essential mineral component of food. The best sources include sea food, eggs, milk and dairy products. Iodine-containing salt is the principal source for all population groups, followed by milk and milk products such as yogurt, cheese, and cottage cheese (Kursa et al. 2005; Řehůřková and Ruprich 2013). However, using milk as an iodine source is problematic due to its varying iodine content. The iodine level varies depending on the iodine content in the feed given to the dairy animals (determined by a transfer from the soil to the feed plant sources), in water, added mineral feed supplements, as well as the use of iodine preparations used as teat disinfectants. These preparations used in postmilking contribute largely to changes in the milk iodine content (Soriguer et al. 2011; Schöne et al. 2017). The stage of lactation was confirmed as a source of iodine content variation in bovine milk. The iodine content positively correlated with the lactose content and increased in early lactation (Trávníček et al. 2013).

Iodine reserves in the soil play an important role and affect the iodine content in feeds and thereby also in ruminant milk (Hejtmánková et al. 2006). According to Oliveriusová (1997), the parent rocks' composition determines the primary iodine content in the environment in the conditions of the Czech Republic. From this point of view, the territory of the Czech Republic is formed by three geological groups: mainly granite and gneiss with almost zero iodine content, longer volcanic rocks in western Bohemia with a higher iodine content and the last Quaternary sediments including the Pannonian clays in South Moravia with relatively the highest iodine content. However, none of the rock types forming the territory of the Czech Republic contains such an amount of iodine that would ensure its sufficient entry into the food chain (Trávníček et al. 2013).

The effect of the diet composition and iodine feed supplementation on the iodine content in milk is well known. The iodine content can also be influenced by various other factors such as the herd size, seasonality, farming practices (organic and conventional farming) or the breed effect. The aim of the study was to supplement the missing data on the actual content of iodine in the milk of small ruminants, as one of the important sources for human nutrition.

\section{Materials and Methods}

Samples

Bulk milk samples of sheep and goat milk were taken from different parts of the Czech Republic. The sampling was performed during the lactation period on each farm (Table 1). Seasonality was assessed for both types of milk and the seasons were as follows: spring (April to May), summer (June to August), autumn (September).

Table 1. Sampling scheme.

\begin{tabular}{lcrrrrrrrrr}
\hline \multirow{2}{*}{ Season } & \multicolumn{3}{c}{ Goats } & \multicolumn{3}{c}{ Sheep } \\
\cline { 2 - 11 } & & C & & NS & NF & NS & NF & NS & NF & NS \\
\hline I & 5 & 11 & 5 & 7 & 4 & 9 & 6 & 11 \\
II & 5 & 20 & 5 & 17 & 4 & 19 & 6 & 17 \\
III & 5 & 9 & 5 & 7 & 4 & 4 & 6 & 8 \\
\hline
\end{tabular}

NF - number of farms; NS - number of samples; C - conventional farm; O - organic farm; I - spring; II - summer; III - autumn 


\section{Goat milk}

Bulk goat milk samples originated from 5 conventional $(n=40)$ and 5 organic farms $(n=31)$. The farms were divided into small ( $\leq 50$ animals), medium (51-150), and large $(\geq 151)$ herds (Tables 2 and 3 ). The goat breeds were White Shorthair, Brown Shorthair and their hybrids, and Anglo-Nubian. For statistical evaluation, the breeds were divided, based on their number of samples as follows: White Shorthair $(n=39)$ and others $(n=32)$. The grazing season was from May to October. The diet was similar for all of the evaluated farms and contained the concentrate, haylage, hay and a mineral lick ad libitum with an iodine concentration of 100 to $120 \mathrm{mg} \cdot \mathrm{kg}^{-1}$, without other additional iodine supplementation in the feed and without an iodine disinfectant in the hygiene regime programme.

Table 2. Iodine content $(\mu \mathrm{g} / \mathrm{l})$ in individual types of raw milk by farming practice.

\begin{tabular}{lccccccrc}
\hline Milk & Farm & NF & NS & Mean & SD & Median & Min & Max \\
\hline \multirow{4}{*}{ Goat } & C & 5 & 40 & 248.30 & 104.53 & 292 & 9 & 363 \\
& O & 5 & 31 & 251.58 & 78.56 & 290 & 75 & 352 \\
& $\mathrm{C}+\mathrm{O}$ & 10 & 71 & 249.73 & 93.46 & 290 & 9 & 363 \\
\hline \multirow{3}{*}{ Sheep } & $\mathrm{C}$ & 4 & 32 & 248.28 & 106.72 & 288 & 37 & 483 \\
& $\mathrm{O}$ & 6 & 36 & 278.36 & 48.76 & 295 & 171 & 385 \\
& $\mathrm{C}+\mathrm{O}$ & 10 & 68 & 264.21 & 82.10 & 295 & 37 & 483 \\
\hline
\end{tabular}

NF - number of farms; NS - number of samples; C - conventional farm; O - organic farm; SD - standard deviation;

Min - minimum value; Max - maximum value

Table 3. Iodine content $(\mu \mathrm{g} / \mathrm{l})$ in goat raw milk from conventional and organic farms by herd size.

\begin{tabular}{rcccccrrr}
\hline & Farm & NF & NS & Mean & SD & Median & Min & Max \\
\hline \multirow{2}{*}{ C } & small & 2 & 17 & 195.53 & 136.24 & 282 & 9 & 323 \\
& medium & 2 & 18 & 289.56 & 47.57 & 303 & 169 & 363 \\
& large & 1 & 5 & 279.20 & 44.44 & 297 & 220 & 322 \\
\hline \multirow{3}{*}{ O } & small & 2 & 15 & 201.53 & 82.75 & 211 & 75 & 296 \\
& medium & 1 & 5 & 305.00 & 9.30 & 307 & 290 & 315 \\
& large & 2 & 11 & 295.55 & 34.55 & 303 & 189 & 352 \\
\hline \multirow{2}{*}{$\mathrm{C}+$ O } & small & 4 & 32 & $198.34^{\mathrm{A}}$ & 112.61 & 249 & 9 & 323 \\
& medium & 3 & 23 & $292.91^{\mathrm{B}}$ & 42.51 & 307 & 169 & 363 \\
& large & 3 & 16 & $290.44^{\mathrm{B}}$ & 40.53 & 303 & 189 & 352 \\
\hline
\end{tabular}

Different superscripts indicate significant differences: $P<0.001$ (small $\times$ medium and large), $P<0.01$ (medium $\times$ large); NF - number of farms; NS - number of samples; C - conventional farm; O - organic farm; SD - standard deviation; Min - minimum value; Max - maximum value

\section{Sheep milk}

Bulk sheep milk samples were collected from 4 conventional $(n=32)$ and 6 organic farms $(n=36)$. The farms were divided into small ( $\leq 50$ animals), medium (51-150) and large $(\geq 151)$ flocks (Table 2 and 4$)$. The sheep breeds were East Friesian, Lacaune, Cigaja and Romanov. For statistical evaluation, the breeds were divided, based on the number of milk samples, as follows: East Friesian $(n=16)$, Lacaune $(n=29)$ and others (Cigaja and Romanov together; $\mathrm{n}=23$ ). The grazing season was from April to October and, in addition to pasture, the diet included the haylage, concentrate, hay, and a mineral lick ad libitum as in goats.

\section{Sample analysis}

The milk samples were transported chilled to the laboratory, homogenized and alkali treated (digested) in the presence of $1 \mathrm{ml} 2 \mathrm{M}$ potassium hydroxide, $1 \mathrm{ml}$ of $10 \%$ zinc sulphate and a spoon point (a few crystals) of potassium chlorate were added to $0.5-1 \mathrm{~g}$ of milk and dried at $105^{\circ} \mathrm{C}$. Mineralization was then carried out at a temperature gradient of up to $620^{\circ} \mathrm{C}$. Iodine was determined by the spectrophotometric method according to Sandell-Kolthoff, based on the catalytic action of iodide ions in the oxidoreduction of $\mathrm{Ce}^{4+}$ and $\mathrm{As}^{3+}(\mathrm{Bedna} r \mathrm{r}$ et al. 1964). By this method, total iodine content is assessed in both inorganic and organic protein-bound forms. The limit of detection is $15 \mu \mathrm{g} / \mathrm{kg}$. The reaction course is a function of the iodine level in the solution, making it possible to determine iodine by measuring the decline in $\mathrm{Ce}^{4+}$. The reaction is terminated by adding brucine 
Table 4. Iodine content $(\mu \mathrm{g} / \mathrm{l})$ in sheep raw milk from conventional and organic farms by herd size.

\begin{tabular}{lccccccrr}
\hline & Farm & NF & NS & Mean & SD & Median & Min & Max \\
\hline $\mathrm{C}$ & small & 1 & 5 & 360.40 & 74.00 & 342 & 290 & 483 \\
& medium & 2 & 21 & 202.76 & 99.48 & 215 & 37 & 316 \\
& large & 1 & 6 & 314.17 & 12.58 & 310 & 304 & 338 \\
\hline $\mathrm{O}$ & small & 1 & 3 & 216.33 & 17.56 & 218 & 198 & 233 \\
& medium & 3 & 22 & 272.27 & 46.16 & 293 & 171 & 325 \\
& large & 2 & 11 & 307.45 & 40.24 & 307 & 216 & 342 \\
\hline $\mathrm{C}+$ O & small & 2 & 8 & $306.38^{\mathrm{A}}$ & 93.69 & 305 & 198 & 483 \\
& medium & 5 & 43 & $238.33^{\mathrm{b}}$ & 83.75 & 273 & 37 & 325 \\
& large & 3 & 17 & $309.82^{\mathrm{A}}$ & 32.75 & 307 & 216 & 342 \\
\hline
\end{tabular}

Different superscripts indicate significant differences: $P<0.05$ (small $\times$ medium), $P<0.01$ (medium $\times$ large); $\mathrm{NF}$ - number of farms; NS - number of samples; C - conventional farm; O - organic farm; SD - standard deviation; Min - minimum value; Max - maximum value

which forms colour adducts with unreacted $\mathrm{Ce}^{4+}$, and the absorbance at $430 \mathrm{~nm}$ of the resultant reddish quinoid $\mathrm{Ce}^{4+}$ complexes is measured spectrophotometrically (Specord 200 Plus, ANALYTIK JENA AG, Germany). To validate the method, the results of this method were compared with ICP-MS and ion-liquid chromatography with electronchemical detection with identical results. Comparison of this spectrophotometric method with measurement by IPV-MS was already reported (Haap et al. 2017).

\section{Statistical analysis}

To evaluate the significance of the studied effects, the generalized linear models with gaussian or gamma error distribution with log-link function, were computed in the R software, version 3.6.1 (R, 2019) with the package MASS (Venables and Ripley 2002). The models were created separately for each of the three species with the iodine content as a dependent variable. As independent variables, we put four fixed effects together: the farming type (conventional and organic), seasonality $(\mathrm{I}=$ spring, $\mathrm{II}=$ summer, III $=$ autumn), the breed, and the herd size. Every model contained all four independent variables and related $P$ values were evaluated for each fixed effect of the model. Microsoft Excel 2013 was used to create a boxplot and calculate basic descriptive statistics (mean, standard deviation, median, minimum and maximum values). Besides, selected mean values of the significant fixed effects were compared with unpaired $t$-test and the $P$ values were put in the descriptive tables.

\section{Results}

\section{Iodine content in milk}

The mean iodine concentrations in goat and sheep milk including both farming practices (C and $\mathrm{O}$ ) were similar and without significance: 249.73 and $264.21 \mu \mathrm{g} / \mathrm{l}$, respectively (Table 2). In terms of dietary exposure, the optimum iodine content in milk is 100-200 $\mu \mathrm{g} / \mathrm{l}$, according to EU norms No. 2015/861 (Regulations EU 2015). This optimal range was achieved only in $13 \%$ and $10 \%$ of sheep and goat milk samples, respectively. Iodine concentrations below $100 \mu \mathrm{g} / \mathrm{l}$ were in $11 \%$ of goat milk and in $7 \%$ of sheep milk samples. In contrast, iodine concentrations above $200 \mu \mathrm{g} / \mathrm{l}$ were found in the majority of milk samples (both 79\%).

\section{Influence of farming practices}

The iodine content in conventional and organic goat milk was 248.30 and $251.58 \mu \mathrm{g} / \mathrm{l}$, respectively; in conventional and organic sheep milk it was 248.28 and $278.36 \mu \mathrm{g} / \mathrm{l}$, respectively (Table 2). Using statistical model evaluation, we found no significant effect comparing conventional and organic farming practices (Tables 2 and 6) for both of animal species. 
Table 5. Iodine content $(\mu \mathrm{g} / \mathrm{l})$ in raw milk in individual seasons.

\begin{tabular}{lcccccrr}
\hline Milk & Season & NS & Mean & SD & Median & Min & Max \\
\hline \multirow{4}{*}{ Goats } & I & 18 & 256.94 & 95.04 & 287 & 10 & 356 \\
& II & 39 & 246.36 & 101.20 & 297 & 9 & 363 \\
& III & 14 & 249.86 & 71.94 & 264 & 121 & 352 \\
\hline \multirow{3}{*}{ Sheep } & I & 20 & 256.65 & 88.93 & 294 & 37 & 385 \\
& II & 36 & 265.78 & 88.34 & 297 & 43 & 483 \\
& III & 12 & 272.08 & 48.80 & 282 & 188 & 342 \\
\hline
\end{tabular}

I - spring; II - summer; III - autumn; NS - number of samples; SD - standard deviation; Min - minimum value; Max - maximum value

Table 6. Effect of farming type, breed, herd size and seasonality on iodine content in raw milk.

\begin{tabular}{llccc}
\hline & & DF & Wald test & $P$ \\
\hline \multirow{6}{*}{ Goats } & Farming type & 1 & 0.16 & 0.69205 \\
& Breed & 1 & 1.45 & 0.22836 \\
& Herd size & 2 & 22.40 & 0.00001 \\
& Seasonality & 2 & 0.35 & 0.83900 \\
\hline \multirow{6}{*}{ Sheep } & Farming type & 1 & 0.12 & 0.72584 \\
& Breed & 2 & 11.10 & 0.00389 \\
& Herd size & 2 & 7.89 & 0.01939 \\
& Seasonality & 2 & 0.53 & 0.76716 \\
\hline
\end{tabular}

DF - degree of freedom; $P$ - significance level
Influence of herd size

The results of iodine content in milk depending on the herd size are summarized in details in Tables 3, 4 and 6. The farm size affected the iodine concentration in goat milk, with higher values being found in medium- and large-sized farms (292.91 and $290.44 \mu \mathrm{g} / \mathrm{l}$, respectively). The differences were significant between small vs. large and medium $(P<0.001)$ and between large

and medium farms $(P<0.01)$. The values for sheep milk, however, differ only little in this study. The highest mean iodine concentration was found on large and small farms (309.82 and $306.38 \mu \mathrm{g} / \mathrm{l}$, respectively) and significant differences were found between small and medium $(P<0.05)$ and between medium and large farms $(P<0.01$; Tables 4 and 6$)$.

\section{Seasonal and breed effect}

We did not observe any significant seasonal effect during lactation in any kind of milk and the iodine content was almost unchanged (Tables 5 and 6).

Regarding the effect of the animal breed on the iodine content of milk, we found a significant effect among breeds only in sheep milk (Table 6). Using the following unpaired $t$-test, we confirmed the significant-differences $(P \leq 0.001)$ between East Friesian breed and the Lacaune and others (Cigaja and Romanov together). Due to the small number of animals studied, we can not definitely confirm this conclusion.

\section{Discussion}

\section{Iodine content in milk}

Our results confirmed that means of iodine concentrations in goat and sheep milk were comparable (249.73 and $264.21 \mu \mathrm{g} / \mathrm{l}$, respectively). Niero et al. (2019) monitored the iodine content of raw sheep and goat milk. Iodine detection and quantification were carried out through an ICP-MS analyzer. They detected a big difference between sheep and goat milk; the mean of iodine content was 192.64 and $575.42 \mu \mathrm{g} / \mathrm{kg}$, respectively. On the contrary, some studies have reported a relatively high iodine concentration of $675 \pm 154 \mu \mathrm{g} / \mathrm{l}$ in sheep milk (Ferri et al. 2003; Schöne and Rajendram 2009). Concentrations of iodine exceeding $500 \mu \mathrm{g} / \mathrm{l}$ are undesirable. Other authors reported 
relatively low values for sheep milk (80 to $104 \mu \mathrm{g} / \mathrm{l}$ ) and lower than $80 \mu \mathrm{g} / \mathrm{l}$ for goat milk (Paulíková et al. 2008; Raynal-Ljutovac et al. 2008). Iodine concentrations in milk below $60 \mu \mathrm{g} / \mathrm{l}$ are a sign of iodine deficiency in small ruminants (Groppel 1993). These values also indicate a low soil iodine content. The iodine content in soil and soil water is correlated with the iodine content in vegetation (Konečný et al. 2020). In accordance with our results, some studies also mentioned a higher iodine content in sheep and goat milk compared to EU norm No. 2015/861, with the same feeding regime. On the other hand, some studies suggest that the iodine content in goat milk is higher than in sheep milk (Groppel 1993; Meschy 2000).

\section{Influence of farming practices}

There is a lack of sources dealing with the influence of the type of farming practices on the iodine content in milk of small ruminants. Rozenská et al. (2011) found a significantly higher iodine concentration on two conventional farms compared to four organic sheep farms (mean 351.1 vs. $39.1 \mu \mathrm{g} / \mathrm{kg}$ ). In case of goat farms, they monitored only big farms keeping about 400-600 goats. The total mean iodine concentration was $458.7 \pm 109.3 \mu \mathrm{g} / \mathrm{kg}$ (Rozenská et al. 2013). Other published studies related to cow's milk are in agreement with ours. For example, Van de Kamp et al. (2019) did not detect significant differences in the milk iodine concentration between conventional and organic farms. On the other hand, many studies showed significantly higher milk iodine concentrations from conventional production compared to organically produced cow milk (Bath et al. 2012; Payling et al. 2015; Walther et al. 2018). This phenomenon is likely due to the farming practice, where organic diets do not meet the estimated dietary requirements of an iodine content of $0.50 \mathrm{mg} / \mathrm{kg}$ of dry matter (Flachow sky 2007). In our study, iodine-based disinfectants were not used before milking on any of the farms. Some authors agree that the treatment of teats with iodine-containing preparations (with $0.3-0.5 \%$ iodine) significantly increased the iodine content in milk (Galton 2004; Castro et al. 2012). However, according to others, the teat disinfectant had no effect on the iodine content in milk, even they reported higher iodine concentrations in conventional milk, compared to organic milk but without significance (Vorlová et al. 2014).

\section{Influence of herd size}

The differences between the herd sizes were significant in our work. Only little information is available regarding the influence of the farm size on the iodine content of milk of small ruminants. Trávníček and Kursa (2001) described a mean iodine content of $243.3 \mu \mathrm{g} / \mathrm{l}$ in sheep milk and $142.1 \mu \mathrm{g} / \mathrm{l}$ in goat milk from small farms using mineral licks. Rozenská et al. $(2011,2013)$ determined iodine concentrations of 576.7 and $123.5 \mu \mathrm{g} / \mathrm{kg}$ on large sheep farms $(>300)$ and $27.36-56.46 \mu \mathrm{g} / \mathrm{kg}$ on small farms $(<30)$. The difference between the two different sized farms was highly significant as was ours $(P<0.01)$. Another monitoring found that the iodine level in goat milk from large farms (400-600 animals) exceeded $450 \mu \mathrm{g} / \mathrm{l}$ (Dahl et al. 2003).

\section{Seasonal and breed effect}

We did not confirm any significant seasonal influence in our study. The non-significant tendencies were in line with some of the results regarding goat milk (Dahl et al. 2003). Rozenská et al. (2013) compared the iodine content in goat milk in April, July, and September. According to our results, the values of iodine content varied and no differences in the means were found $(P<0.26)$. In a previous study, Rozenská et al. (2011) confirmed a significantly higher iodine content of $75.42 \mu \mathrm{g} / \mathrm{kg}$ in sheep milk in the winter period (October-March) compared to $37.84 \mu \mathrm{g} / \mathrm{kg}$ in the summer period (AprilSeptember). 
We found no significant effect among breeds in goat milk. The same conclusion was confirmed in some studies. The authors were unable to reveal the effect of breed on the iodine content and did not find any significant differences in iodine levels between White and Brown Short-haired goats and their 3 different lineages (Dahl et al. 2003; Rozenská et al. 2013; Van der Reijden et al. 2018). In sheep, Rozenská et al. (2011) did not find significant differences between two breeds, Romanov sheep and Merino. Significant fluctuations in iodine levels in the milk of small ruminants are primarily due to the composition of diets, including pasture. Soils in the Czech Republic are deficient in iodine as a consequence of the geographical and geological conditions. Another factor that affects the level of iodine in milk is the use of mineral supplements. For small ruminants, supplementation may help to improve the dietary management, as has been the case for cows on commercial dairy farms.

\section{Acknowledgments}

This research was supported by the Ministry of Agriculture of the Czech Republic, grant no. NAZV KUS QJ 1230044, MZe RO1420 and Internal Grant Agency of the UPVS Brno, grant no. 25/2014/ FVHE.

\section{References}

Andersson M, de Benoist B, Darnton-Hill I, Delange F 2007: Iodine deficiency, health consequences, assessment and control. In Iodine Deficiency in Europe: A continuing public health problem. WHO Library Cataloguing in Publication Data. Published jointly with Unicef. Press in France, pp. 8-19

Bath SC, Button S, Rayman MP 2012: Iodine concentration of organic and conventional milk: implication for iodine intake. British J Nutr 107: 935-940

Bath SC, Steer CD, Golding J, Emmett P, Rayman MP 2013: Effect of inadequate iodine status in UK pregnant women on cognitive outcomes in their children: results from the Avon Longitudinal Study of Parents and Children (ALSPAC). Lancet 382: 331-337

Bednáŕ J, Röhling S, Vohnout S 1964: A contribution to the determination of protein iodine in blood serum (in Czech). Českosl Farm 13: 203-209

Castro SI, Berthiaume R, Robichauda A, Lacasse P 2012: Effects of iodine intake and teat-dipping practices on milk iodine concentrations in dairy cows. J Dairy Sci 95: 213-220

Costeira MJ, Oliveira P, Santos NC, Ares S, Saenz-Rico B, de Escobar GM, Palha JA 2011: Psychomotor development of children from an iodine-deficient region. J Ped 159: 447-453

Dahl L, Opsahl JA, Meltzer HM, Julshamn K 2003: Iodine concentration in Norwegian milk and dairy products. British J Nutr 90: 679-685

Ferri N, Ulisse S, Aghini-Lombardi F, Grazianto MF, Di Mattia T, Russo FP, Arizzi M, Baldini E, Trimboli P, Attanasio D, Fumarola A, Pinchera A, D'Armiento M 2003: Iodine supplementation restores fertility of sheep exposed to iodine deficiency. J Endocrinol Invest 26: 1081-1087

Flachowsky G 2007: Iodine in animal nutrition and iodine transfer from feed into food of animal origin. Lochmann Inf 42: 47-59

Galton DM 2004: Effects of an automatic postmilking teat dipping system on new intra mammary infections and iodine in milk. J Dairy Sci 87: 18-25

Groppel B 1993: Jodmangel beim Tier. In Mineralstoffe und Spurenelemente in der Ernährung. Verlag Media Touristik, Gersdorf, pp. 127-156

Haap M, Roth HJ, Huber T, Dittmann H, Wahl R 2017: Urinary iodine: comparison of a simple method for its determination in microplates with measurement by inductively-coupled plasma mass spectrometry. Sci Rep 7: 39835

Hejtmánková A, Kuklík L, Trnková E, Dragounová H 2006: Iodine concentrations in cow’s milk in Central and Northern Bohemia. Czech J Anim Sci 51: 189-195

Iodine Global Network: Israelis have among world's worst iodine deficiency. Available at: https:/www.ign.org/ p142002691.html. Last modified March 27. 2017. Accessed March 3, 2021

Kavř́k R, Paskerová H, Řehůřková I, Ruprich J 2013: Dynamics of seasonal variation of iodine content in various types of milk available to consumers (in Czech). In Proceedings of the $10^{\text {th }}$ Conference of Iodine Day: Iodine supplementation as prevention of thyroid diseases and sources of dietary exposure. The National Institute of Public Health Prague, České Budějovice, Czech Republic, 15 May 2013, pp. 48-51

Konečný R, Šeda M, Fiala K, Švehla J, Macháčková H, Trávníček J 2020: The iodine content in areas with enhanced landscape management in the Czech Republic. J Elem 25: 1233-1242

Kursa J, Herzig I, Trávníček J, Kroupová V 2005: Milk as a food source of iodine for human consumption in the Czech Republic. Acta Vet Brno 74: 255-264

Lazarus JH 2014: Iodine Status in Europe. Europ Thyr J 3: 3-6 
Meschy F 2000: Recent progress in the assessment of mineral requirements of goats. Liv Prod Sci 64: 9-14

Niero G, Franzoi M, Vigolo V, Penasa M, Cassandro M, Boselli C, Giangolini G, De Marchi M 2019: Validation of a gold standard method for iodine quantification in raw and processed milk, and its variation in different dairy species. J Dairy Sci 102: 4808-4815

Oliveriusová L 1997: Iodine content in the Czech environment (in Czech). How to solve the iodine deficiency in our diet. In Proceedings of the National Institute of Public Health Prague, p. 8

Paulíková I, Seidel H, Nagy O, Kováč G 2008: Milk iodine content in Slovakia. Acta Vet Brno 77: 533-538

Payling LM, Juniper DT, Drake C, Rymer C, Givens DI 2015: Effect of milk type and processing on iodine concentration of organic and conventional winter milk at retail: implications for nutrition. Food Chem 178: 327-330

Raynal- Ljutovac K, Lagriffoul G, Paccard P, Guillet I, Chilliard Y 2008: Composition of goat and sheep products: An update. Small Rum Res 79: 57-72

Regulations. Commission Implementing Regulation (EU) No. 2015/861 of 3 June 2015 concerning the authorisation of potassium iodide, calcium iodate anhydrous and coated granulated calcium iodate anhydrous as feed additives for all animal species

Rozenská L, Hejtmánková A, Kolihová D, Miholová D 2011: Selenium and iodine content in sheep milk from farms in central and East Bohemia. Sci Agric Bohem 42: 153-158

Rozenská L, Hejtmánková A, Kolihová D, Miholová D 2013: Effects of lactation stage, breed, and lineage on selenium and iodine contents in goat milk. Czech J Food Sci 31: 318-322

Řehůřková I, Ruprich J 2013: Dietary supply of iodine to Czech population and its most important sources (in Czech). In Proceedings of the $10^{\text {th }}$ Conference of Iodine Day: Iodine supplementation as prevention of thyroid diseases and sources of dietary exposure. The National Institute of Public Health Prague, České Budějovice, Czech Republic, 15 May 2013; pp. 13-19

Sargison ND, West DM, Clark RG 1998: The effects of iodine deficiency on ewe fertility and perinatal lamb mortality. N-Z Vet J 46: 72-75

Schöne F, Rajendram R 2009: Iodine in farm animals. In: Preedy VR, Burrow GN, Watson RR (Eds): Comprehensive Handbook of Iodine: Nutritional, Biochemical, Pathological and Therapeutic aspects. Academic Press, Elsevier, San Diego, 1312 p.

Schöne F, Spörl K, Leiterer M 2017: Iodine in the feed of cows and in the milk with a view to the consumer's iodine supply. J Trace Elem Med Biol 39: 202-209

Soriguer F, Gutierrez-Repiso C, Gonzalez-Romero S, Olveira G, Garriga MJ, Velasco I, Santiago P, de Escobar GM, Garcia-Fuentes E 2011: Iodine concentration in cow's milk and its relation with urinary iodine concentrations in the population. Clin Nutr 30: 44-48

Trávníček J, Fiala K, Šeda K, Dušová H, Peksa M, Kroupová V 2013: Results of iodine monitoring in bulky feed, water and soil (in Czech). In Proceedings of the $10^{\text {th }}$ Conference of Iodine Day: Iodine supplementation as prevention of thyroid diseases and sources of dietary exposure. The National Institute of Public Health Prague, České Budějovice, Czech Republic, 15 May 2013, pp. 34-36

Trávníček J, Kursa J 2001: Iodine concentration in milk of sheep and goats from farms in South Bohemia. Acta Vet Brno 70: 35-42

Van de Kamp ME, Saridakis I, Verkaik-Kloosterman J 2019: Iodine content of semi-skimmed milk available in the Netherlands depending on farming (organic versus conventional) and heat treatment (pasteurized versus UHT) and implications for the consumer. J Trace Elem Med Biol 56: 178-183

Van der Reijden OL, Galetti V, Hulmann M, Krzystek A, Haldimann M, Schlegel P, Manzocchi E, Berard J, Kreuzer M, Zimmermann MB, Herter-Aebeli I 2018: The main determinants of iodine in cows' milk in Switzerland are farm type, season and teat dipping. Br J Nutr 119: 559-569

Venables WN, Ripley BD 2002: Modern applied statistics with S. Fourth edn. Springer-Verlag New York Inc., $501 \mathrm{p}$.

Verma I, Sood R, Juneja S, Kaur S 2012: Prevalence of hypothyroidism in infertile women and evaluation of response of treatment for hypothyroidism on infertility. Int J App Basic Med Res 2: 17-19

Vorlová L, Hodulová L, Borkovcová I, Přidalová H, Kostrhounová R, Klimešová-Vyletělová M, Šustová K 2014: Iodine content in bulk tank milk samples in relation to dairy farm size. Acta Vet Brno 83: 9-13

Walther B, Weschler D, Schlegel P, Haldiman M 2018: Iodine in Swiss milk depending on production (conventional versus organic) and on processing (raw versus UHT) and the contribution of milk to the human iodine supply. J Trace Elem Med Biol 46: 138-143

WHO 1993: Global prevalence of iodine deficiency disorders. Micronutrient deficiency information system (MDIS) working paper No. $1,80 \mathrm{p}$.

Zimmermann MB 2009: The iodine deficiency. Endocrin Rev 30: 376-408 